BLS 33, No 1 2007. DOI: http://dx.doi.org/10.3765/bls.v33i1.3549

(published by the Berkeley Linguistics Society and the Linguistic Society of America)

\title{
Indonesian Money, Balinese People: Codeswitching and Numerals in Balinese Sociopolitical Discourse*
}

\author{
EDMUNDO LUNA \\ University of California, Santa Barbara
}

\section{Introduction}

Past studies on codeswitching (which is defined here as the alternation between two or more languages within a single conversation) have highlighted many of its characteristics that play unique roles in what we know about language and interaction. These characteristics include its structural properties, as exemplified by such models as the Linear Equivalence Constraint (Poplack 1980:73, Poplack 1981), the Matrix Language Frame Model (Myers-Scotton 1993), a typological approach (Muysken 2000), among others. These characteristics also include its socio-interactional motivations (Gumperz 1964, Zentella 1982, 1997), as well as motivations that combine structural and socio-interactional considerations, such as Shenk (2006), which investigates the role of prosody in codeswitching within interactions from a discourse-functional perspective.

Given the breadth of the codeswitching literature, the contribution of this study is an attempt to address the following questions: how and where does codeswitching fit in interactional contexts where multilingual speakers are restricted to particular codes in their native language? These questions highly reflect the interactional situation for bilingual speakers of Balinese and Indonesian (both Austronesian languages of the Sundic sub-branch) who participate in sangkep banjar or paruman banjar, periodic meetings of the banjar, an essential sociopolitical institution in Bali, Indonesia (Eiseman 1990, Geertz 1975, HauserSchäublin 1997, Hobart 1975, Howe 2001, Warren 1995).

This study will demonstrate that even in linguistically constrained interactions, codeswitching can and does indeed occur once an appropriate trigger has been invoked. In this case, one possible trigger is the semantic domain of money and finance, which prompts the use of Indonesian rather than Balinese numerals and

\footnotetext{
* The data collected for this study were made possible by a University of California Pacific Rim Research Program Mini-Grant (Project 05-1436) awarded in 2005. I am extremely grateful to the numerous friends and colleagues who have assisted me during my fieldwork in Bali. I would like to thank Susanna Cumming and Petra Scott Shenk, whose invaluable suggestions and assistance have greatly enhanced the quality of the present study. Thanks also to the various participants at BLS 33 for their comments. Any remaining errors are my own.
} 
Edmundo Luna

figures. This particular motivation for codeswitching suggests some connection of the national and provincial governments' role to the financial matters of any given banjar.

This study has two goals. One goal is to show that sangkep participants index matters directly dealing with institutions above the village level (e.g. the provincial and national level) by codeswitching to Indonesian at the mention of numerals and financial figures. The other goal is to show that banjar are responding to competing pressures: one is to preserve goals and practices that are associated with Balinese cultural identity through the use of Balinese; the other is to report to and acknowledge national- and provincial-level institutions for which banjar are also responsible through the use of Indonesian.

\section{Background}

\subsection{The banjar}

The banjar, as stated above, is an essential sociopolitical institution in Bali; in fact, it is the smallest recognized political unit on the island. A typical banjar is made up of several kuren (households), each of which is represented by the active membership of married males (i.e. the household heads). However, the banjar is far from a homogeneous institution - one would certainly expect to notice some differences from one banjar to the next. That being said, there are a number of characteristics that all banjar have in common: 1) Villages have at least one banjar (but many have more than one); 2) membership to a banjar is compulsory once a man marries. The banjar where he and his family take up membership is usually the one of his father, provided there is enough room to allow more members; 3) each banjar has a charter of regulations (awig-awig), which sets terms and conditions for office term limits, fines, ritual and legislative punishment, and so on; and 4) the banjar itself oversees the social and spiritual life of the village, mostly through resolutions passed by consensus during the sangkep, which usually take place in the bale banjar (a pavilion dedicated for banjar use), but can take place in other consecrated assembly space.

\subsection{Language Use in Bali}

The Balinese language is famous for its socially constrained lexicon, which will be referred to here as speech styles (cf. Errington 1988 on a similar phenomenon in the related language Javanese). The speech style conventions in Balinese have been characterized in the following manner (Eiseman 1990), even though the actual situation is much more complex (Arka 2005, Artini 1993, Howe 1989, 2001):

- Low speech styles are used when addressing those of lower castes, as well as intimates and family members.

- High speech styles are used when addressing those of higher castes.

- Middle speech styles are used when addressing those whose castes are unknown. After the castes between the speaker and addressee have been ascertained, the participants adjust their speech styles accordingly. Middle speech styles are also used when a high-caste speaker and a low-caste 


\section{Indonesian money, Balinese people: Codeswitching}

addressee are talking about a third person who is of higher caste than either participant.

Thus, if one were to ask someone if s/he wanted to take a bath, there are (at least) three ways of expressing this, as illustrated in (1):

$$
\begin{array}{llll}
\text { LOW } & \text { Cai/Nyai } & \text { lakar mandus? } \\
\text { MID } & \text { Jerone } & \text { jagi masiram? } \\
\text { HIGH } & \text { Iratu } & \text { jagi masucian? } \\
& \text { you } & \text { FUT bathe } \\
\text { “Will you take a bath?” (from Eiseman 1990:139; translation mine) }
\end{array}
$$

These speech style conventions are used in most informal interactions (informal conversations, market transactions, and so on).

The meetings of the banjar (sangkep/paruman banjar), on the other hand, are unique in this regard due to a temporary suspension of these speech style conventions that is enacted within these contexts. Instead, only high and middle speech styles are used as a preventative measure against insulting anyone in the assembly. Reverting to using low speech styles as per informal interactional practices is highly undesirable since

"the use of improper or insulting language is a serious offence which causes ritual pollution of the whole banjar. This state must be annulled, ideally paid by the offender" (Hobart 1975:73).

The use of high and middle speech styles is greatly admired in Balinese interactions (Howe 2001:91), since it reflects the highly desired social quality of alus 'refined', as opposed to kasar 'coarse, uncouth'. Reflecting the alus quality is key for a speaker attempting to convey respect to other participants, especially when assembly consensus on potentially contentious issues is sought. On the other hand, Indonesian has been regarded as more "neutral" in cases where it is spoken along with regional languages, with formulaic roles to play in public discourse contexts (Anderson 1990, Durie 1995).

\section{Data}

The corpus used for this study is comprised of two meetings that were recorded in two separate villages in Bali in October 2005. These two meetings, identified here as PENG05 and BAT05, occurred in two villages approximately 10 miles apart within the southeastern regency of Gianyar.

PENG05 took place in a bale banjar and lasted approximately 2.5 hours, while BAT05 took place in the jaba tengah (middle courtyard) of a pura dalem (a foundational temple dedicated to the spirits of the dead) and lasted approximately 1.5 hours.

The recordings were then transcribed into Intonation Units (IUs), based on the transcription system described in Du Bois et al. (1993). This resulted in PENG05

\footnotetext{
${ }^{1}$ Nyai is the feminine second person pronoun, which is only found in low speech styles.
} 
having 4991 IUs, and BAT05 having 3272 IUs. The meeting data were also analyzed for clauses (i.e. they had to contain at least one predicate), which resulted in 1776 clauses in PENG05 and 1457 clauses in BAT05.

\section{Instances of Codeswitching}

Clauses were counted as tokens of codeswitching if more than one element were uttered in Indonesian. An example of such a token (with the Indonesian elements in boldface) is illustrated in (2):

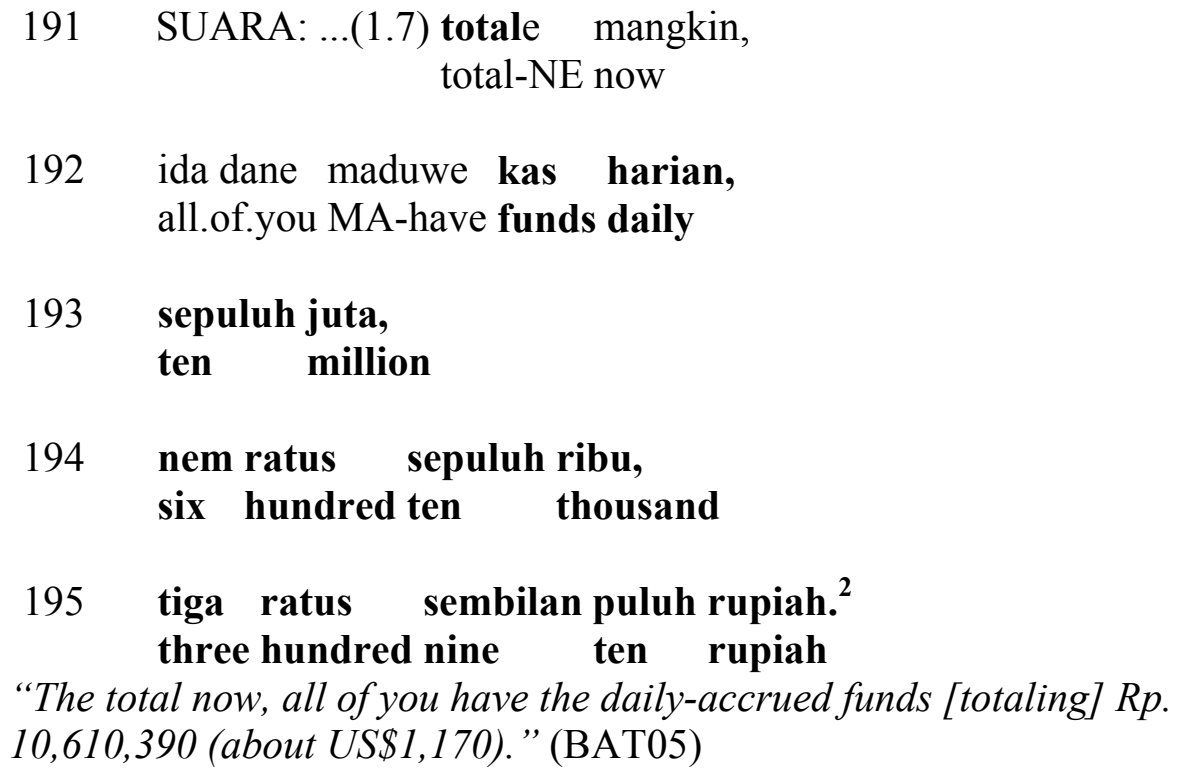

"The total now, all of you have the daily-accrued funds [totaling] Rp.

10,610,390 (about US\$1,170).” (BAT05)

Clauses with only one lexical or grammatical item in Indonesian were treated as containing borrowings rather than as tokens of codeswitching. An example of this is illustrated in (3):

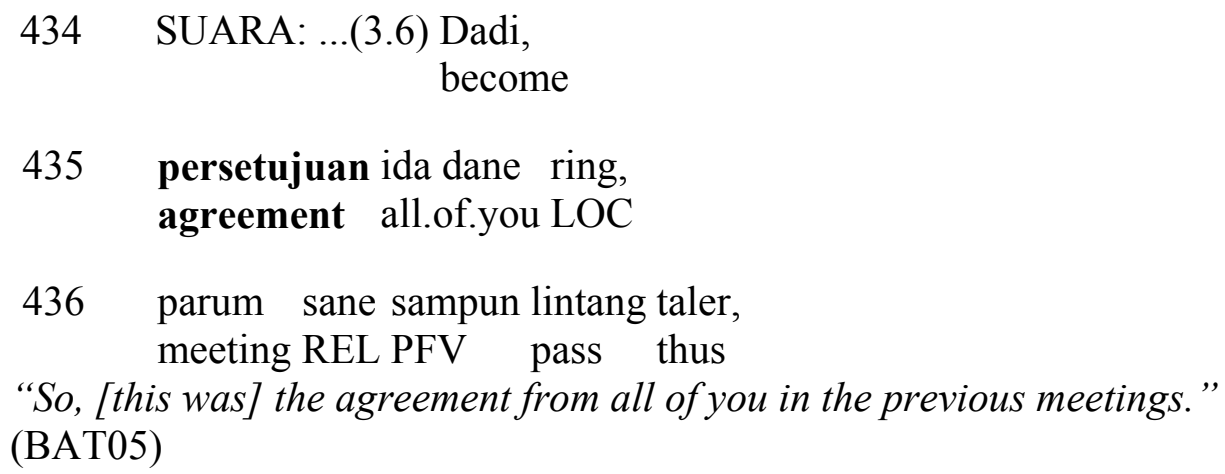

From this analysis, codeswitching is rather rare in these meetings, although it does occur more frequently in BAT05 (above 20\%) than in PENG05 (less than $10 \%$ ), as shown in (4):

\footnotetext{
${ }^{2}$ The rupiah is the current national currency of Indonesia.
} 
(4)

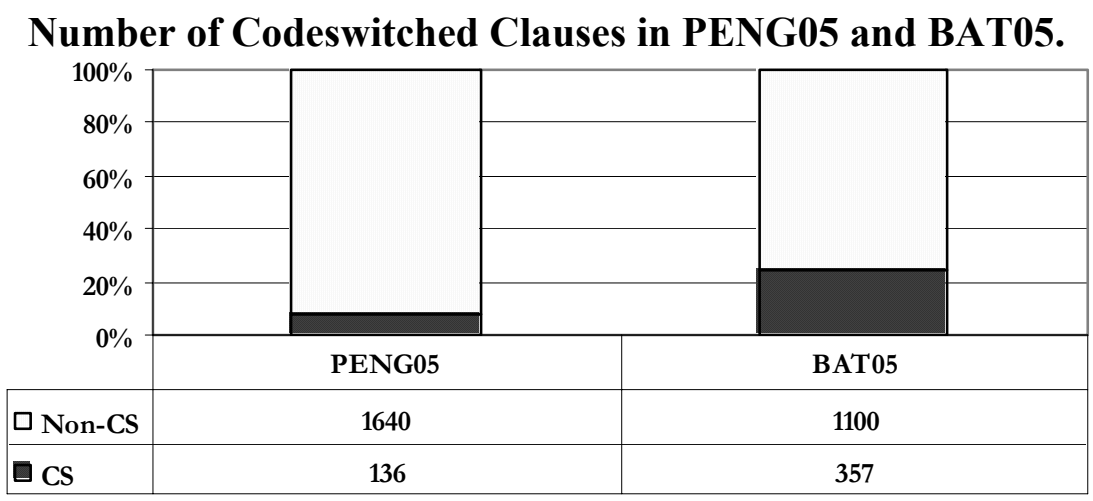

Even though figures in (4) suggest that codeswitching into Indonesian is still rather rare in these meetings, the discussions in sections 4 will demonstrate that numerals and financial figures play large roles in triggering the codeswitching that does occur in the data.

\section{Numerals and Codeswitching}

There are 144 tokens of both Balinese and Indonesian numerals from the two meetings. Examples with both types are given in (5) and (6) respectively, with the Balinese numerals in italics and the Indonesian numerals in boldface:

KANDRA: pecalang niki, village.security.force this

621 duang dasa dini. two:NAS ten here

"The 20 members of the village security force here." (PENG05)

(6) 340 SUARA: ...hasil pasar duwene, profit market possess-NE

$341 \quad$...(1.6) sat=u, one

342 ..seratus dua puluh lima juta, one.hundred two ten five million

343 nem ratus tujuhbelas, six hundred seventeen

344 ..ribu, thousand 


\section{5 empat ratus rupiah. \\ four hundred rupiah}

"The profit from the market [amounts to] Rp. 125,617,400 (more than

US\$13,000)." (BAT05)

In terms of distribution and frequency of Balinese vs. Indonesian numerals as predicates, NP modifiers, and adverbials, there is a visible difference between the two meetings, as shown in (7):

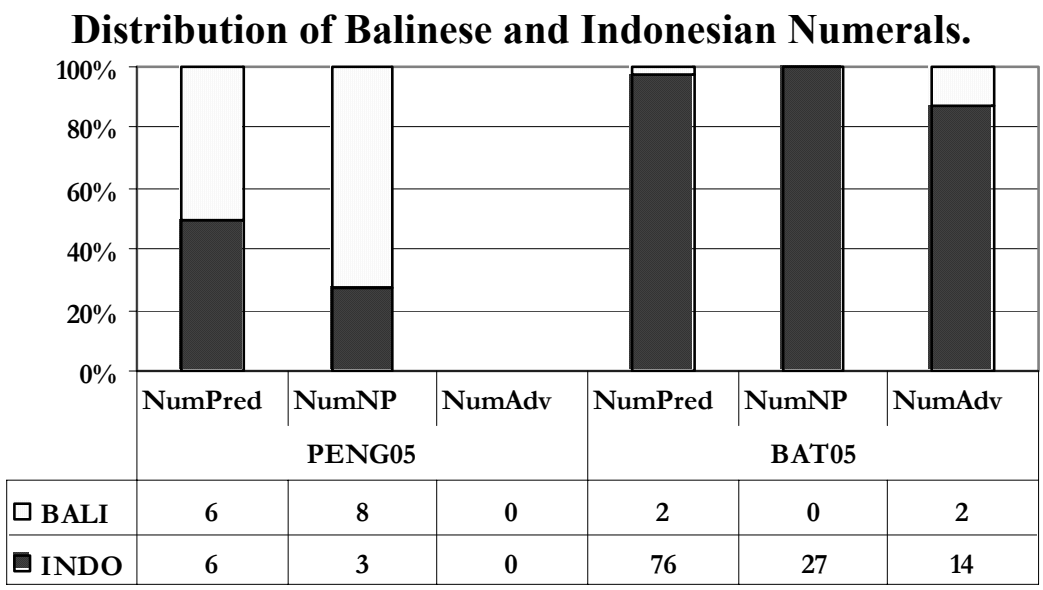

As the figures in (7) show, the numerals in PENG05 show an equal distribution between Balinese and Indonesian numeral predicates, and a majority of Balinese NP- modifying numerals. On the other hand, the numerals in BAT05 show a strong tendency for Indonesian numerals overall.

Of course, one obvious question that emerges from these figures is what factors would motivate such a distribution. One hypothesis is the structural differences between the Balinese and Indonesian numerals being a primary factor. In order to test this hypothesis, comparisons between corresponding numerals in Balinese and Indonesian must be made. An initial comparison is presented in (8): 
Indonesian money, Balinese people: Codeswitching

(8)

Some Numerals in Balinese and Indonesian.

\begin{tabular}{|c|c|c|}
\hline \hline Numeral & Balinese & Indonesian \\
\hline \hline 'one' & sa & satu \\
\hline 'two' & dua (L)/ kalih (H) & dua \\
\hline 'three' & telu (L)/ tiga (H) & tiga \\
\hline 'four' & pat & empat \\
\hline 'five' & lima & lima \\
\hline 'ten' & dasa & sepuluh \\
\hline 'twenty' & duang dasa (L)/kalih dasa (H) & duapuluh \\
\hline 'twenty-one' & selikur & duapuluh satu \\
\hline 'twenty-two' & dualikur & duapuluh dua \\
\hline 'twenty-five' & selae & duapuluh lima \\
\hline 'thirty' & telung dasa (L)/tigang dasa (H) & tigapuluh \\
\hline 'thirty-five' & pasasur & tigapuluh lima \\
\hline 'one hundred' & satus & seratus \\
\hline 'two hundred' & satak & dua ratus \\
\hline
\end{tabular}

As illustrated above in (8), both numeral systems are basically decimal, but the Balinese system also contains several suppletive forms, especially for higherorder numerals, which came about by several intersecting cultural practices such as special names for Chinese cash coin combinations and the like, e.g. selae 'twenty-five' < sa- 'one' + lawe 'thread (of 25 Chinese cash coins)' and satak 'two hundred' < sa- 'one' + atak 'thread of 200 coins' (Comrie 2005, Eiseman 1990). Thus, one could ask at this point if the codeswitching into Indonesian via numerals is due to the complexity resulting from the presence of suppletive forms within the Balinese numeral system.

However, this seems not to be the case, since there are some higher-order Balinese numerals in the data, as illustrated in (9) and (10):

(9) 947 KANDRA: ...ngaturang ring, N-offer-ANG LOC

948 ..kenten bunga-bunga niki, thus profit.account this

949 ...satak seket, two.hundred fifty

"[I will] mention something about the 250 profit accounts." (PENG05)

KANDRA: ..katahnyane karobelah yuta, at.most one.hundred.fifty million 


\section{Edmundo Luna}

770 ..plaus bunga, t.o.offering flower

771 nika.

that

“At most [there will be] 150 million plaus offerings.” (PENG05)

Therefore, other factors have to be considered, as the following discussion in section 5 will demonstrate.

\section{Quantified Monetary Figures vs. Other Entities}

As demonstrated in section 4, numeral complexity has little to do with the distribution of Balinese and Indonesian numerals in the meeting data. Instead, it appears that one of the main factors of Balinese vs. Indonesian numeral distribution is the manner in which monetary figures are expressed during these meetings, as illustrated by the examples in (11) and (12):

79

$$
\begin{array}{r}
\text { SUARA: ...(1.8) Sisa kas lama, } \\
\text { remaining funds long.time }
\end{array}
$$

80 ..ida dane maduwe sembilan juta, all.of.you MA-have nine million

81 empat ratus delapanbelas ribu, four hundred eighteen thousand

$82 \quad$ lima ratus.

five hundred

"The remaining funds in the long-term account all of you have [amount to] Rp 9,418,500 (under US\$1,000).” (BAT05)

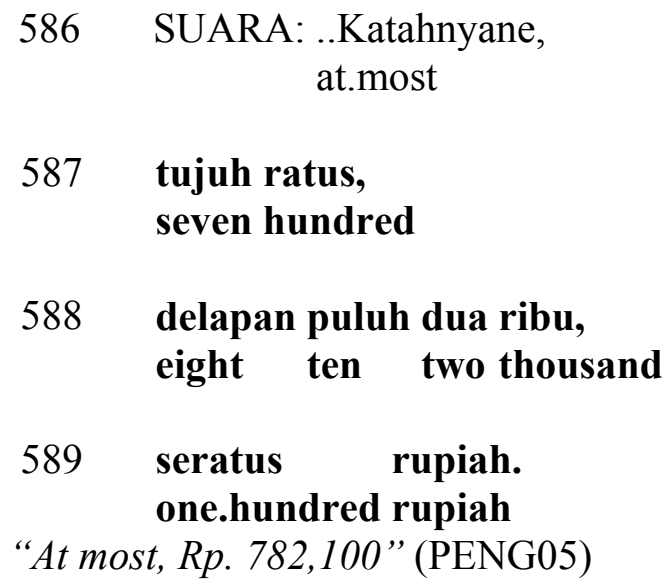

In contrast, other entities, e.g. people, tend to be quantified with Balinese numerals, as illustrated in examples (13) and (14): 
Indonesian money, Balinese people: Codeswitching

(13) 619 KANDRA: akehnyane, at.most

620 pecalang niki, village.security.force this

621 duang dasa dini. two: NAS ten here

"At most, the 20 members of the village security force here." (PENG05)

(14) 238 PANYARIKAN: sane nenten ngrauhang, REL NEG N-come-ANG

239 wantah, only

240 ...(2.9) ulung dasa, eight:NAS ten

$241 \quad$...kutus diri. eight CL:person

“Just 88 (people) did not come." (PENG05)

As shown in (13) and (14), the entities pecalang niki 'the village security force' and sane nenten ngrauhang 'those who have not come' are quantified with Balinese rather than Indonesian numerals.

In terms of distribution, the tendencies for Indonesian numerals quantifying financial figures and for Balinese numerals quantifying other quantified entities appear to hold, as suggested by the figures in (15):

Distribution of Numerals Quantifying Financial Figures vs. Other Entities.

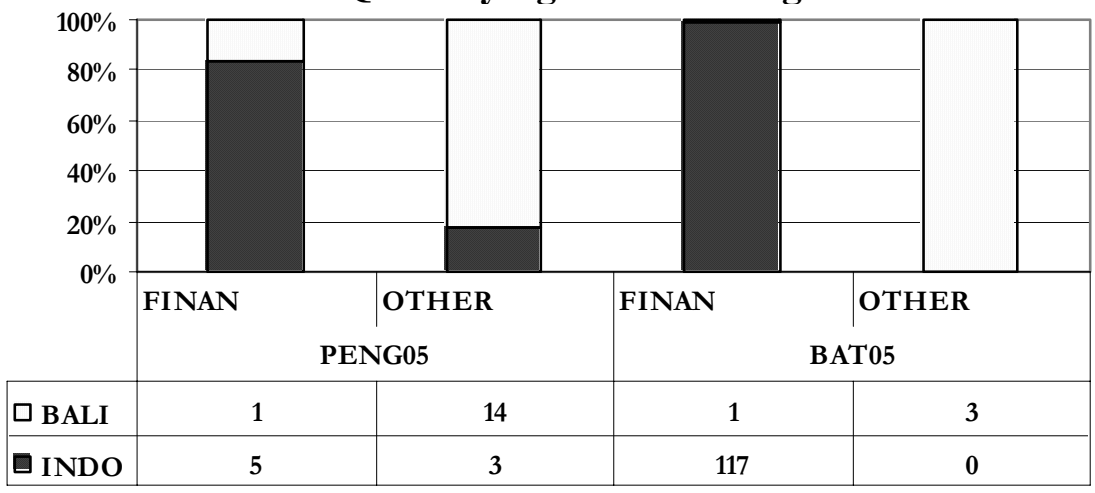


Edmundo Luna

As illustrated in (15), PENG05 shows the majority of financial figures being quantified by Indonesian numerals, and other entities by Balinese numerals. Furthermore, this tendency is stronger still in BAT05.

\section{Motivations for Codeswitching with Numerals in the sangkep}

Now that a primary factor for determining the distribution between Indonesian and Balinese numerals (and subsequent codeswitching) has been found, the question that remains to be addressed is the range of possible motivations for codeswitching with numerals in these meetings.

It appears that the use of Indonesian numerals within the sangkep is motivated primarily by the banjar's roles and responsibilities in several national- and provincial-level institutions. For example, one consideration is that banjar located in villages within or near heavily touristed areas (such as the villages in the present study) are responsible for administering funds which enter the local economy via various funding machines, such as taxes levied at markets with heavy tourist traffic and at tourist-themed restaurants and hotels which are under the auspices of the PHRI (Perhimpunan Hotel Restoran Indonesia 'The Indonesian Hotel and Restaurant Association'). For banjar which do not encounter a high volume of tourists, there are other supra-village institutions for which they take responsibility. One example of this is the LPD (Lembaga Perkreditan Desa 'Village Credit Council'), a provincial level program which is intertwined with village-level activities at the financial level. In essence, the financial figures associated with these various institutions comprise a possible "bridge" for Balinese speakers to codeswitch into Indonesian.

\section{Concluding Remarks}

To summarize, it appears that Balinese speakers in a sangkep banjar can codeswitch to Indonesian when numerals associated with financial figures are mentioned. The motivation for this is most likely the fact that financial figures are most often associated with national- and provincial-level institutions, which occur in the form of taxes, programs with financial credit incentives, and so on.

Thus, the codeswitching attested in these meetings index the competing pressures for which the banjar is responsible: while the institution is ultimately responsible for preserving much of the Balinese cultural identity (part of which is using Balinese), it also presents itself as a viable and influential political institution in the national (i.e. Indonesian) level, as indexed through the use of Indonesian.

\section{Abbreviations:}

-ANG derivational -ang suffix (primarily valency-changing and some idiomatic functions; cf. Sidhakarya 1998)

CL classifier

EXIST existential verb

HESIT hesitation particle

LOC locative

MA- "S-Trigger” prefix (see Cumming 1991 for "trigger" terminology) 
N- "A-Trigger" prefix

NAS nasalized numeral form (cf. Eiseman 1990)

-NE definite/possession marker (cf. Luna and Cumming 2006)

NEG negation particle

PFV perfective

REL relativizer

\section{Transcription conventions after Du Bois et al. (1993)}

$\begin{array}{ll}. & \text { final intonation contour } \\ , & \text { continuating intonation contour } \\ -- & \text { truncated intonation contour } \\ - & \text { truncated word } \\ \% & \text { glottal stop } \\ = & \text { prosodic lengthening } \\ . . & \text { short pause } \\ \ldots & \text { long pause } \\ \text { (x.y) } & \text { length of long pause (in seconds) }\end{array}$

\section{References}

Anderson, B.R.O'G. 1990. Language and Power: Exploring Political Cultures in Indonesia. Ithaca: Cornell University Press.

Arka, I Wayan. 2005. Speech Levels, Social Predicates and Pragmatic Structure in Balinese: A Lexical Approach. Pragmatics 15(2/3):169-203.

Artini, Luh Putu. 1993. Style Shifting in Balinese Dialogue: A Discourse-Based Study. La Trobe Papers in Linguistics 6.

Comrie, Bernard. 2005. Endangered Numeral Systems. In Jan Wohlgemuth and Tyko Dirksmeyer, eds., Bedrohte Vielfalt: Aspekte Des Sprach (En) Tods [Endangered Diversity: Aspects of Language Death], 203-230. Berlin: Weissensee Verlag.

Cumming, Susanna. 1991. Functional Change: The Case of Malay Constituent Order. New York: Mouton de Gruyter.

Du Bois, J. W., Stephan Schuetze-Coburn, Danae Paolino, and Susanna Cumming. 1993. Outline of Discourse Transcription. In Jane A. Edwards and Martin D. Lampert, eds., Talking Data: Transcription and Coding Methods for Language Research, 45-89. Hillsdale, NJ: Lawrence Erlbaum.

Durie, Mark. 1995. Framing Acehnese: Language Choices and Discourse Structures in Aceh. Presented at BLS 21.

Eiseman, Fred B. Jr. 1990. Bali: Sekala and Niskala, Vol. 2: Essays on Society, Tradition, and Craft. vol. 2. Hong Kong: Periplus Editions Ltd.

Errington, J. J. 1988. Structure and Style in Javanese: A Semiotic View of Linguistic Etiquette. Philadelphia: University of Pennsylvania Press.

Geertz, Hildred, and Clifford Geertz. 1975. Kinship in Bali. Chicago; London: University of Chicago Press.

Gumperz, John J. 1964. Linguistic and Social Interaction in Two Communities [December]. American Anthropologist 66(6). 
Edmundo Luna

Hauser-Schäublin, Brigitta. 1997. Traces of Gods and Men: Temples and Rituals as Landmarks of Social Events and Processes in a South Bali Village. Berlin: Dietrich Reimer Verlag.

Hobart, Mark. 1975. Orators and Patrons: Two Types of Political Leader in Balinese Village Society. In Maurice Bloch, ed., Political Language and Oratory in Traditional Society, 65-92. London; New York; San Francisco: Academic Press.

Howe, Leo. 1989. Hierarchy and Equality: Variations in Balinese Social Organization. Bijdraagen tot de Taal-, Land- en Volkenkunde:47-71.

Howe, Leo. 2001. Hinduism \& Hierarchy in Bali. Oxford; Santa Fe: James Currey; School of American Research Press.

Luna, Edmundo, and Susanna Cumming. 2006. Polysemy, Homophony, Definiteness, and Possession: The Case of Balinese $-(N) E$. Paper presented at 10th International Conference on Austronesian Linguistics (10ICAL), Puerto Princesa, Philippines.

Muysken, Pieter. 2000. Bilingual Speech: A Typology of Codemixing. Cambridge: Cambridge University Press.

Myers-Scotton, Carol. 1993. Common and Uncommon Ground: Social and Structural Factors in Codeswitching. Language in Society 22:475-503.

Poplack, Shana. 1980. Sometimes I'll Start a Sentence in Spanish Y Termino En Espanol: Toward a Typology of Code-Switching. Linguistics 18:581-616.

Poplack, Shana. 1981. Quantitative Analysis of a Functional and Formal Constraint on Codeswitching. Centro de Estudios Puertorriqueños, Working Papers (2).

Shenk, Petra Scott. 2006. The Interactional and Syntactic Importance of Prosody in Spanish-English Bilingual Discourse. International Journal of Bilingualism 10(2):179-205.

Sidhakarya, Wayan. 1998. The -Ang and -in Suffixes as Verbal Case Markings in Balinese. In Shobhana L. Chelliah and Willen J. de Reuse, eds., The Fifth Annual Meeting of the Southeast Asian Linguistics Society, 317-333. Tempe, AZ: Arizona State University.

Warren, Carol. 1995. Adat and Dinas: Balinese Communities in the Indonesian State. Oxford; Singapore; New York: Oxford University Press.

Zentella, Ana Celia. 1982. Codeswitching and Interactions among Puerto Rican Children. In J. Amastae and Elías-Olivares, eds., Spanish in the United States: Sociolinguistic Aspects, 386-412. Cambridge, New York: Cambridge University Press.

Zentella, Ana Celia. 1997. Growing up Bilingual: Puerto Rican Children in New York. Oxford: Blackwell.

Edmundo Luna

Department of Linguistics

UC Santa Barbara

3607 South Hall

Santa Barbara, CA 93106-3100

ecluna@umail.ucsb.edu 